\section{Adequacy Of Activity Oriented Technique In Instructing Science To VII Class Understudies}

\author{
Mehwish Arif \\ Assistant Professor Department Of Education Sindh \\ Madressatul Islam University, Karachi, Pakistan
}

\author{
G Open ACCESS \\ The American Journal of \\ Social Science And \\ Education Innovations \\ JULY 2020 \\ Page No.: 129-133 \\ Volume-II Issue-VII \\ PUBLISHED: 30 JULY 2020 \\ www.usajournalshub.com/inde \\ x.php/tajssei \\ Copyright: Original content \\ from this work may be used \\ under the terms of the \\ Creative Commons Attribution \\ 4.0 licence.
}

\begin{abstract}
The motivation behind the exploration was to examine the adequacy of action situated strategy in showing science in understudies of in optional classes. The Test bunch educated by action situated strategy was contrasted and the benchmark group which was instructed in the traditional course book approach. Maintenance test consequences of the two gatherings were contrasted altogether and furthermore objectivewise with discover whether various sorts of exercises has any huge impact on the maintenance limit of understudies. The strategy utilized in the examination is exploratory technique. The reliant variable is the accomplishment of understudies while the autonomous variable is the instructing strategy.
\end{abstract}

Keywords: Movement Arranged Strategy, Adequacy, Instructing, Science, Optional School, Understudies, Maintenance, Course book.

\title{
Introduction
}

Today science is advancing at an angry pace and it has outperformed all the supernatural 
occurrences of folklore. There isn't so much as a solitary zone which is forgotten about by the mystical bit of science. By misusing the curious idea of man science continues changing moment by minute and building new information step by step.

"The typical worry of static science is information, particularly of realities or standards, picked up by efficient investigation; a specific part of information managing a collection of realities or facts deliberately masterminded. As opposed to static, the dynamic view dependent on analyze, on a readiness to challenge old authoritative opinion, and on a receptiveness to consider the to be as it truly seems to be".

As indicated by this portrayal science is a "living substance that evolves" and it is energizing. On the opposite side, "science is information or an arrangement of knowledge". This isn't to prevent this view from claiming science in light of the fact that the worried of a researcher not just on the expert individuals of the subject, however a typical man also. Along these lines, science is a way or way for the comprehension of the world and this idea ought to be learns by broad network, particularly younger students.

Action educational program signifies "educational plan structure in which the premiums and reasons for youngsters decide the instructive program of exercises being arranged cooperatively by instructor and students" and action getting the hang of/showing signifies "any learning or showing circumstance, for example, venture work which is portrayed by cooperation with respect to student, instead of latent taking in of data from a talk, talk or watched exhibit" (Universal Word reference of Training).

As per Ediger, 1996 it is significant for the science instructor to give an assortment of learning exercises for students. Customarily the chief point of viable work has been to assist the understudy with understanding the hypothetical thoughts being instructed by the educator. Finagrin and Ingram (1988) disclose numerous chances to permit students to encounter science wonders take care of issues and create research facility and diagnostic abilities. 


\section{Targets}

Following were the fundamental targets of the investigation:

1. To discover the accomplishment of understudies when instructed by action situated technique.

2. To discover the accomplishment of understudies when educated by regular course book approach.

3. To analyze the accomplishment of students instructed by action arranged strategy with traditional course book approach.

\section{Procedure}

\section{Structure}

Test research varies from expressive investigations in which the specialist has some level of power over the factors in question and the conditions under which the factors are watched. Test strategy gives a lot of control and along these lines builds up a deliberate and sensible relationship between controlled factors and watched impacts.

A trial structure to the analyst is the thing that a diagram is to an engineer. It gives the scientist a chance to examinations required by the speculations of the trial and empowers him to make a significant translation of the consequences of the investigation with the assistance of measurable investigation of the information.

The structure chose for the current examination is "Non-equal pre-test - post-test plan. There are two gatherings (control and trial) in this investigation and the two gatherings are looked at in accomplishment test.

\section{Factors}

'Something that can change in esteem and can be estimated is a variable. It tends to be a part of a trial circumstance or a trademark that changes in various people'. For an exploratory examination there are free factors and ward factors. 


\section{Conversation}

The movement arranged strategy will urge the understudies to watch the nature cautiously and this expertise of sharp perception will assist them with understanding the issue all the more plainly and unequivocally. The technique likewise assists with connecting the hypothesis and useful which is preposterous in ordinary course reading approach. As indicated by this investigation the best outcomes are gotten just when singular exercises are given. The showing technique for utilizing just huge gathering (exercises to the entire class like watching graphs, seeing test arrangements and so on.)

The movement arranged strategy can be utilized in all science subjects. Since next to no examination work has been done in showing subjects other than science through action arranged strategies, it could likewise be a zone for additional exploration.

An overview can be led among educators in regards to their feeling about these strategies. Such an investigation will be useful in breaking down the master assessment of educators and furthermore may give an understanding into viable challenges that the instructors could experience in directing such classes.

- The assessment of understudies and their folks can be gathered through a study.

- Further examinations can likewise be led by partitioning various sorts of exercises to check which kind of movement is most appropriate to build the accomplishment and maintenance limit of understudies having a place with various age gatherings.

- The disposition of instructors, understudies, guardians and teachers about bifurcating activityoriented technique can be gathered and broke down. It will be useful in improving the technique and arranging it as per the necessities of the understudies.

- A study should be possible to distinguish the schools in which a few developments are utilized to improve the instructing learning process. The different advancements done and its impact can be examined. 


\section{References}

1. Young, L. J. (1961). Science and Sound judgment. New Paradise: Yale College Press.

2. Ratho, N D. (1994). Science Educational program New Delhi: Revelation Distributing House.

3. Ravi pavan(1978). Science forever Instructors Guide UK: Thomas Nelson and Children Ltd.

4. Petter, A. W. (1981). Measurements in Brain science and Instruction. Bombay: Vakils, Feffer and Simons Ltd.

5. Mosunjac MB (1995). Essential Science Information and Understandig. London: Routledge.

6. Burkhardt T, ( 1988). Worldwide Word reference of Training. 7. New York: Nicholas Distributing Organization.

7. Adi Bhargav, (1997). Accomplishment in Science. New Delhi: Revelation Distributing House. 